mass vaccination of schoolchildren what are the implications for public health policy? Whatever decisions are taken locally or nationally about the school BCG programme the vaccine must continue to be offered to all children in high risk categories. This should include neonates born in urban priority areas, poverty perhaps being a better indication of risk than race. ${ }^{19}$ It must not, however, be given to patients who are immunocompromised, including children with HIV infection, or to those with malignancy, fever, or generalised skin sepsis. ${ }^{20}$

Next, medical vigilance against tuberculosis must continue. A new threat to the steady decline in notification rates is posed by patients with immunosuppression caused by HIV infection. These patients are at increased risk of developing active tuberculosis and acting as a new source for household and other contacts. ${ }^{21}$ Not only immigrants, alcoholics, and old people are at risk $^{12}$ : outbreaks affecting children will still occur $^{22}$ with potential fatal and long term sequelae.

It is for society and the medical profession to answer the major question. When does the effectiveness of chemoprophylaxis and chemotherapy, coupled with the low risk of infection for the individual, make it acceptable to have a few extra cases of tuberculosis because the school vaccination programme has been stopped?

S P CONWAY

Consultant in Paediatrics and Infectious Diseases,

Seacroft Hospital,

Leeds LS14 6UH
Department of Health, Welsh Office, Scottish Home and Health Department. Immunisation against infectious diséase. London: HMSO, 1990):72-89.

Medical Research Council and Chest Disease Unit. Tuberculosis in children: a national surver of notifications in England and Wales in 1983. Arch 1) is Child 1988;63:266-76.

Horne NW. Control and prevention of tuberculosis: a code of practice. Thorax 1984:39:321-5.

4 Joint Tuberculosis Committee of the British Thoracic Society. Control and prevention of tuberculosis. BMF 1983;287:1118-21.

5 Romanus V. Tuberculosis in BCG immunised and unimmunised children in Sweden: a ten-year evaluation following the cessation of general BCG immunisation of the newborn in 1975. Pediatr Infect Dis 1987;6:272-80.

6 Hart PD, Sutherland I. BCG and vole bacillus vaccines in the prevention of tuberculosis in adolescents and early adult life. BMF 1977;ii:293-5.

Public Health Laboratory Service Communicable Disease Surveillance Centre BC(i vaccination. BMF 1983;286:876-7.

8 Lotte A, Wazz-Hockert O, Poisson N, Dumitrescu N, Verron M, Couvet E. BCG complications Adzances in Tuberculosis Research 1984;21:107-93.

9 Curtis HM, Leck I, Bamford FN. Incidence of childhosd tuberculosis after neonatal $\mathrm{BCC}$ vaccination. Lancet 1984; i: 145-8.

10 Sanders R, Dickson MG. BCG vaccine scars: an avoidable problem. BMF 1982;285:1679-80.

11 Medical Research Council and Chest Disease Unit. National survey of tuberculosis in England and Wales in 1983. BM7 1985;291:658-61.

12 Springett VH, Darbyshire JH, Nunn AJ, Sutherland I. Changes in tuberculosis notification rates in the white ethnic group in England and $W^{\prime}$ ales between 1952 and 1983. 7 Epidemiol Community Health 1988:42:370-6.

13 Miller CL, Morris J, Pollock TM. Public Health Laboratory Service inquiry into current BCG vaccination policy. BMf 1984;288:564.

14 Springett VH, Sutherland I. BCG vaccination of school children in England and Wales. Thorax 1990;45:83-8.

15 Ormerod LP. Reduced incidence of tuberculosis by prophylactic chemotherapy in subject showing strong reactions to tuberculin testing. Arch Dis Child 1987;62:1005-8.

16 Joint Tuberculosis Committee of the British Thoracic and Tuberculosis Association. Chemoprophylaxis against tuberculosis in Britain. Tubercle 1973;54:309-16.

17 Stilwell JA. Benefits and costs of schools BCG vaccination programme. BM7 1976; ; 1002-4

18 Sjoumgen I. Practical consequences of estimating the risk of tuberculosis infection on the policy making in Sweden. Bull Int L'nion Tuberc L ung Dis 1984;59:132-3.

19 Cundall DB, Pearson SB. Inner city tuberculosis and immunisation policy. Arch Dis Child 1988;63:96+-5

20 Nimane J, (jrrmonprez A, Burtonbor (i, Francois A, Cornu (i. Disseminated BCG in HIV infection. Arch Dis Child 1988;63:1268-9.

21 Selwyn PA, Hartel D, Lewis VA, et al. A prospective study of the risk of tuberculosis among intravenous drug users with human immunodeficiency virus infection. $N$ Fingl $f$ Med $1989 ; 320: 545-50$.

22 George RH, Gully PR, Gill ON, Innes JA, Bakhshi SS, Connolly M. An outbreak of tuberculosis in a children's hospital. F Hosp Infect 1986;8:129-42.

\title{
Retreat from general practice
}

\section{Dislike of the contract has turned away trainees}

One of the most encouraging features of British medicine over the past 25 years has been the development of planned postgraduate education for general practice. After the earliest initiatives in Inverness and the pioneer work of George Swift in Wessex the BMA, the Royal College of General Practitioners, and the departments of health displayed remarkable unanimity in supporting the creation of training schemes comprising two years in hospital and one year in general practice. The Royal Commission on Medical Education in 1966 pointed the way to legislation introduced a decade ago that required all aspiring principals to complete this three year training period. This structured programme resulted in general practice becoming the most popular career choice of medical graduates, attracting some of the most able young doctors. Its attraction often perplexed their hospital consultants, who nevertheless generously supported the programmes themselves. Vocational training schemes were developed throughout Britain and were oversubscribed some seven or eight times, so that those sitting on appointments committees had a wide choice of the most highly qualified and motivated doctors to appoint to these schemes.

Suddenly, this position has changed, and changed dramatically, since the publication of the general practice contract. Organisers of vocational training schemes throughout Britain have reported a precipitous fall in applicants - by a factor of about five. Whereas last year the appointments committees had a wide range of choice, this year, for the first time in 20 years, many vocational training schemes could not be filled on first advertisement.

Fear is the key to understanding this fall in applications. Undoubtedly young doctors are anxious that the government's intention of encouraging increased list sizes will result in fewer opportunities to obtain partnerships. An expansion of the senior house officer grade in hospital has also provided an opportunity for potential trainees to widen their experience in hospital while waiting for the impact of the new contract to become clearer.

But by far the greatest fear expressed by young doctors is their perception of a changing ethos. They are concerned that a career in general practice will not now fulfil the sense of vocation that drew them to medicine. The idea of serving patients in the community, with extensive clinical freedom, is seen as under threat, with values confused with costs. Even more important, however, is what they see as the sinister intrusion of state direction into clinical relations: general practitioners are being asked to undertake clinical tasks that defy their clinical teaching.

Formal vocational training schemes provide only about half the total entrants to general practice in any year, with the remainder planning their own rotations through hospital posts and general practice. Inevitably the sheer numbers of medical graduates will ensure that there are enough entrants to general practice, but to draw satisfaction from that fact is to fail to comprehend the damage done to the morale of these young doctors. By their reactions they have provided the first audit of the contract in practice. Measurements of fear and lowered morale do not translate easily to the accountant's balance sheet. They are, however, central to the success of any enterprise.

Regional Adviser in General Practice,

A G DONALD

South East Regional Committee for Postgraduate Medical Education,

Edinburgh EH8 9DR 